\title{
Gloom in Latin America
}

\section{São Paulo}

LATIN America has 8.3 per cent of the world's population, but only 2.5 per cent of its engineers and scientists, 1.8 per cent of the resources given to research and development and 1.3 per cent of the authorships of scientific papers. These discouraging statistics provided the backdrop for last week's first meeting of heads of science and technology agencies in Latin America, held in São Paulo at the 'Latin America Memorial', a cultural centre created to help speed integration among the peoples of the continent.

One suggestion was that governments should consider "debt for science" arrangements with foreign creditors. The idea was put forward by Crodowaldo Pavan, president of Brazil's National Council for Scientific and Technological Development $(\mathrm{CNPq})$. Both Pavan and Israel Monsewer, head of Uruguay's National Council for Scientific and Technical Research, said the 80 s were "a lost decade" for Latin America's development.

Despite calls for regional integration, there is a widespread lack of cooperation in research. Bolivia's Jose Antonio Zelaya, responsible for Science and
Technology development at the country's Ministry for Planning, said that he would like to see more multilateral work in areas that affect more than one country, like Amazon research or the study of the River Plate basin. But, participants agreed that cooperation only works well when it is based on specific projects, not "letters of intent" signed by governments.

The meeting was not without dire warnings and prophecies. Some participants fear that interest in Eastern Europe will hit investment and debt-relief in Latin America. "We may lose the last train to the coast", said Brazilian diplomat Celso Luiz Nunes Amorim, who heads the Cultural Department at the Ministry for Foreign relations. "Integration" could help, he said. But another Brazilian, Geraldo Lesbat Cavagnard Filho, director of the Nucleus of Strategic Studies at the State University of Campinas disagreed. Only integration with the rest of the world will provide long-term benefit, he said. Uruguay's Monsewer reminded everyone that Latin America's participation in the world export market dropped from 7.7 per cent in 1960 to 3.9 per cent last year.

Ricardo Bonalume

\section{Red tape still a problem}

\section{São Paulo}

A NEW decree regulating the conduct of scientific expeditions in Brazil came under fire last week at a meeting of the Brazilian Society for the Progress of Science (SBPC). "The intention of the decree is not to foster international scientific cooperation" said SBPC. The society asked government to revoke the decree.

The new decree, passed last month, replaced a 1969 decree which has been a constant source of complaint both inside and outside Brazil, on the grounds that it makes it difficult for foreign scientists to visit the Amazon and other regions of Brazil without years of paper work. "The new decree is better than the old, but it still doesn't settle the basic problem, which is to provide incentives for international cooperation," says anthropologist Eunice Durham, one of SBPC's vicepresidents.

The Ministry of Science and Technology (MCT) defends the new decree. The ministry's secretary-general, mathematician Lindolpho Carvalho Dias, says that if the decree has its faults, scientists need to present suggestions for amendments and not ask to abrogate it.

Expeditions are a sensitive topic in Brazil, and the decree actually avoids using the word. "'Expedition' reeks of colonialism," says Carvalho Dias. The decree talks instead of "collection, by foreigners, of scientific data and material in Brazil".

Carvalho Dias insists that the goal of the decree is to emphasize cooperation. The old decree said that every expedition had to have at least one Brazilian scientist in attendance, which turned the Brazilian researcher into a sort of "police" responsible for the visitors. The new legislation calls for participation of a Brazilian institution instead. This means that the documents required for a permission to "collect" data and material need not be sent to a Brazilian consulate or embassy abroad, but are the responsibility of the partner institution in Brazil.

Waiting periods are also reduced. Under the old decree, foreigners had to submit all documents six months in advance and then wait for permission to be granted. This could take more than a year. The new decree says that it is the ministry who has to give an answer with a explicit deadline, set at four months except under "exceptional" circumstances.

The biggest hurdle, according to SBPC, is the need to consult several different government agencies, depending on the goal of the expedition. To visit the northern region inhabited by the Yanomanmi people, for example, the list would be very long.

\section{Museums make news}

LONDON'S museum worid, not a haven of peace in recent years, has been in the news. again. The Natural History Museum has been the target of protests (page 9), and across the other side of the City, a new museum has been jeopardized by the loss of its major source of funding. The Museum in Docklands project, launched in 1982, may have to cease work on 31 March with the withdrawal of support from the London Docklands Development Corporation (LDDC), the body charged with overseeing the development of the large area vacated by London's docks when the coming of larger ships and containerization made them redundant. The current slump in property values in southeast England

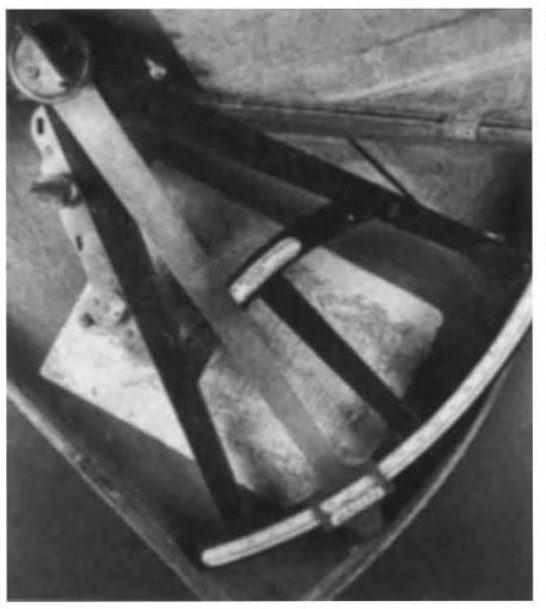

had led the LDDC to look for money-saving measures, although supporters of the museum project argue that without such amenities the docklands area will remain unattractive to developers and would-be inhabitants

Among the 100,000 exhibits in store and awaiting a home are a number of scientific instruments made in the area, including the 'octant' shown above, made in 1770 by Thomas Ripley of Hermitage Basin. C.W.

Because the region is close to the border and there are conflicts with illegal gold prospectors, the military would have to be consulted. Because of the presence of native people, the federal agency dealing with them would need to grant permission. And if geologists are involved the agency responsible for mining will have to have its say. If the research strays into a natural preserve, the environment body will also be involved. The Ministry of Foreign Relations, will also want to make its views known, on top of the agency the decree says is "responsible" for granting permission, the National Council for Scientific and Technological Development (CNPq).

Researchers at the National Institute for Amazon Research complain that government red tape is already luring foreigners to study the rain forest in Costa Rica or Peru, instead of coming to Brazil. Scientists would like CNPq to have sole and complete responsibility for expeditions.

Ricardo Bonalume 